\title{
3. CENOZOIC CONTINENTAL GEOLOGY OF SOUTH AMERICA AND ITS RELATIONS TO THE EVOLUTION OF THE CHILE TRIPLE JUNCTION ${ }^{1}$
}

\author{
Randy Forsythe ${ }^{2}$ and David Prior ${ }^{3}$
}

\begin{abstract}
The Cenozoic magmatic and tectonic histories of the southern Andes adjacent to the Chile Triple Junction (CTJ) reflect the evolution and migration of the triple junction during the last $20 \mathrm{~m} . \mathrm{y}$. in a number of fundamental ways.

Pliocene near-trench magmatism, including the intrusion of calcalkaline stocks within the forearc basement and the creation of the Taitao Ophiolite within the leading edge of the forearc, relates directly to ridge subduction processes.

Distribution and kinematics of faulting, observed geologically and through earthquake seismology, reflect the plate margin kinematics and are also strongly influenced by the thermal, topographic, and kinematic heterogeneities related to the Chile Triple Junction. The most important structure in this respect is the 1000-km-long, trench-parallel, Liquiñe Ofqui Fault (LOF). This extends north from the CTJ and has a predominantly dextral displacement. Complex faulting and related subsidence within the Golfo de Penas basin have continued throughout the late Cenozoic and appear to define a "pull-apart" basin within the South American forearc at the southern trailing edge of the LOF.

The history of the Cenozoic uplift of the Andean divide appears to be dramatically different north and south of the triple junction. The backarc fold-and-thrust belt of southernmost Patagonia appears to end at the present latitude of the triple junction. Passage of slab windows corresponding to ridge segments subducted during the late Cenozoic corresponds spatially with arc gaps and centers of backarc alkalic flood basalts.
\end{abstract}

\section{INTRODUCTION}

Has ridge collision left its geologic fingerprint in the onshore areas? Specifically, have the Cenozoic subduction-related tectonic and magmatic processes that shaped this portion of the Andean orogenic belt been significantly altered by the triple junction's passage? Before discussing these effects, a general background of the geology of the southern Andes is presented.

A geological map of the southern Andes is shown in Figure 1. The basement to the Patagonian Andes comprises metasediments and metavolcanics that have undergone polyphase deformation. These rocks have yielded late Paleozoic metamorphic ages (Hervé et al., 1988; Pankhurst et al., 1992) and are found in two discontinuous belts. One is located along the western margin of the coastal islands and has been progressively exhumed during the Tertiary and Quaternary. The other is located along the main Cordillera and has been exhumed concurrent with development of the Late Cretaceous to Tertiary Patagonian fold-and-thrust belt. Protoliths in the western belt include pillow lavas, cherts, limestones, and turbidites (Forsythe, 1982; Hervé et al., 1981). These rocks are mostly at greenschist facies or less, although a number of glaucophane localities have been reported (Hervé et al., 1987). The inner belt of basement has similar protoliths and also comprises inliers of late Paleozoic and early Mesozoic calcalkaline plutonic rocks. The metasediments and metavolcanics record a late Paleozoic phase of subduction-related accretion, deformation, and metamorphism along the Proto-Pacific margin of Gondwana (Hervé et al., 1987). The plutonic rocks are viewed as forming the arc associated with the forearc assemblages (op. cit.).

\footnotetext{
${ }^{1}$ Behrmann, J.H., Lewis, S.D., Musgrave, R.J., et al., 1992. Proc. ODP, Init. Repts., 141: College Station, TX (Ocean Drilling Program).

${ }^{2}$ Department of Geography and Earth Sciences, University of North Carolina/Charlotte, Charlotte, NC 28223, U.S.A.

${ }^{3}$ Department of Earth Sciences, Liverpool University, Liverpool L69 3BX, U.K.
}

The two basement belts are divided by a 50 - to $75-\mathrm{km}$-wide zone of dominantly plutonic and volcanic rocks. These rocks include (1) Cretaceous and Cenozoic calcalkaline I-type granitoids (the Patagonian Batholith), (2) local roof pendants and down-faulted blocks of deformed Cretaceous and Tertiary volcanic and volcaniclastic units, (3) late Tertiary to Holocene volcanic and volcaniclastic deposits that are largely undeformed and unconformably overlie the older plutonic and volcanic units, and (4) in the south, a Jurassic to Cretaceous ophiolite sequence.

Lower elevation areas to the east of the continental divide are thought of as the "backarc." The oldest rocks of the province are Jurassic volcanic, volcaniclastic, and siliciclastic units that represent the exposed portions of an intracontinental extensional province that existed throughout much of southern South America during the Jurassic to earliest Cretaceous (Bruhn et al., 1978; Gust et al., 1985). A contrast can be seen in the post-Jurassic stratigraphy between the northern and southern sectors of the Patagonian backarc. In southern Patagonia, the Jurassic has been overlain by flysch of Lower Cretaceous to Eocene age (Malumian and Ramos, 1984). At the latitude of the triple junction, Lower Cretaceous marine shales and limestones have been superceded by Upper Cretaceous terrestrial siliciclastic sediments with a reversion to marine sedimentation that spans the upper Oligocene to Miocene (Skarmeta, 1978; Ramos, 1989). Widespread continental Miocene molasse (Ramos, 1989) is common to both northern and southern segments.

\section{MAGMATIC EFFECTS OF TRIPLE JUNCTION MIGRATION}

Magmatic processes that may be linked to the migration of the Chile Triple Junction include (1) near-trench ophiolite formation and emplacement, (2) near-trench calcalkaline intrusions, (3) cessation of "arc" volcanism over the evolving subducted "slab window," (4) a shift in the chemistry of Holocene arc volcanism after ridge collision, and (5) eruption of backarc flood basalts during the late Tertiary over the "slab windows" as they pass further under the backarc areas. 


\section{Near-trench Magmatism}

Forsythe et al. (1986), Kaeding et al. (1990), and Mpodozis et al. (1985) presented field, radiometric, and geochemical data bearing on the two near-trench magmatic suites exposed on the Taitao Peninsula (Fig. 2). Samples from the plutons and the Taitao Ophiolite yielded radiometric ages that are clustered between 3 and $5 \mathrm{Ma}$. One foraminifer-bearing strata within the ophiolite yielded a late Pliocene/Pleistocene age. The calcalkaline stocks intrude late Miocene marine strata.

The ophiolite, in addition to including basaltic rocks, contains basaltic andesites, dacites, and rare rhyodacites and rhyolites. Major element, rare earth element (REE), and isotope geochemistries (Kaeding et al., 1990) suggest that the magmatic processes included a combination of fractional crystallization and partial contamination by a crustal component. Some of the differentiated units in the ophiolite are chemically indistinguishable from some of the calcalkaline intrusions (Kaeding et al., 1990). A basaltic parent, possibly linked to the ophiolite, was also likely to have fractionated and assimilated crustal material to form the magmas represented by the distributed calcalkaline stocks. The exact origin of the ophiolite is a matter of debate. Two end-member models are considered: (1) the ophiolite is a fossil ridge segment obducted and thrust into the leading edge of the South American forearc immediately following ridge collision and (2) an incipient rift propagated into the forearc over the site of ridge collision just as the active spreading ridge passed into the trench under the toe of the inner trench wall. We favor the latter model because of the consanguineous development and geochemical similarity of the distributed calcalkaline stocks and differentiated lavas within the ophiolite. Shallow-water sediments interbedded with the lavas and blocky subaerial lavas within the ophiolite lend further support for this model.

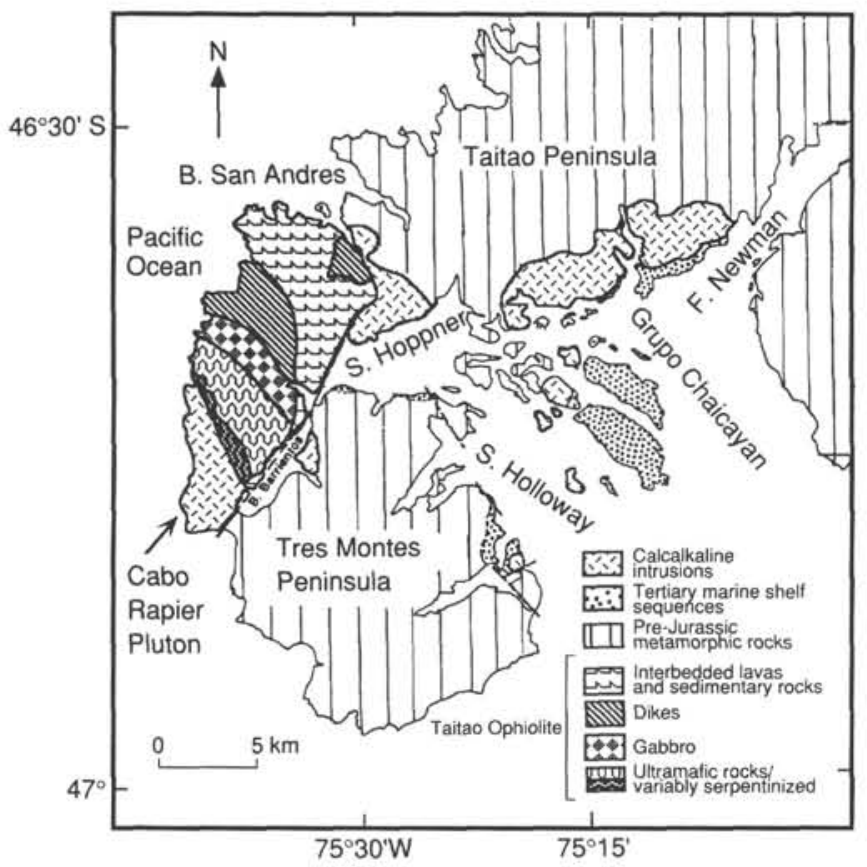

Figure 2. Simplified geologic map of the Taitao and Tres Montes peninsulas. The Pliocene Taitao Ophiolite and distributed calcalkaline stocks and plutons represent near-trench magmatism associated with triple junction evolution. Modified after Forsythe et al. (1986).

\section{Arc Volcanism}

Approximately $200 \mathrm{~km}$ inland of the buried extension of the Peru-Chile Trench lies the main axis of Holocene calcalkaline volcanism (Fig. 3). This line of volcanism has been divided into northern and southern zones. The northern segment is referred to as the Southern Volcanic Zone (SVZ), and the southern segment as the "Austral" Volcanic Zone (AVZ).

The SVZ is composed of approximately 40 Holocene stratovolcanoes and 20 or more Pliocene-Pleistocene stratovolcanoes. The centers are distributed in a 70-km-wide, north-south-trending belt, which in its southern areas runs adjacent to the arc-parallel LOF Zone. The volcanic centers have a spacing of 20 to $60 \mathrm{~km}$ along the axis of the arc. The arc has been calculated as being positioned approximately $90 \mathrm{~km}$ above the subducted slab (Thorpe and Francis, 1979), and the crust has been estimated as approximately 30 to $35 \mathrm{~km}$ thick (Cummings and Schiller, 1971). The dominant lavas of the SVZ are high-aluminum basalts and basaltic andesites, with less abundant andesites and dacites (Katsui, 1972; Vergara and Munizaga, 1974; Lopez-Escobar et al., 1977; Moreno and Parada, 1976). In the northern portions of the SVZ $\left(33^{\circ}-34^{\circ} \mathrm{S}\right)$, amphibole-bearing andesites are common, whereas in the southern extents of the zone, volcanoes have a common bimodal high-Albasalt and dacite composition $\left(37^{\circ}-\right.$ $41^{\circ} \mathrm{S}$ ). Geochemically, the SVZ volcanoes are distinct from those farther north in the Andean Central Volcanic Zone (Thorpe and Francis, 1979; Lopez-Escobar et al., 1977). The position of the axis of volcanism in the SVZ was remarkably constant throughout the Late Cretaceous, Tertiary, and Quaternary (Munizaga et al., 1988). The average distance of the SVZ from the Peru-Chile Trench decreases systematically from around $250 \mathrm{~km}$ in the north to 180 to $200 \mathrm{~km}$ in the south. This is probably a manifestation of the changing character of the subduction system as the CTJ is approached.

Between the southernmost volcano of the SVZ (Hudson) and the northernmost of the AVZ (Lautaro) lies a 300-km gap in the volcanic arc. South of this gap, the four stratovolcanoes of the AVZ have a spacing of 100 to $170 \mathrm{~km}$. Cande and Leslie (1986) and Forsythe and Nelson (1985) have argued that the gap is directly related to the existence of a slab window produced by the progressive subduction of the Chile spreading ridge-transform system. The correlation of the gap in the volcanic arc to the inferred position of the "slab window" remains a compelling argument for the importance of subducted oceanic crust in the mechanisms for generation of calcalkaline volcanic arcs.

Geologists generally hold that the calcalkaline volcanism of the AVZ reflects the continued $2 \mathrm{~cm} / \mathrm{yr}$ convergence of the Antarctic Plate with the South American Plate. The four northern stratovolcanoes have a uniform arc-trench distance of about 200 $\mathrm{km}$, and the position of the arc has remained fixed over time (Nelson et al., 1988; Hervé et al., 1988).

\section{Backarc Volcanism}

To the east of the arc are extensive areas of alkalic flood basalts. While the area of backarc flood basalts extends well to the north (almost to the latitude of Mendoza and Santiago) and includes lavas as old as the Eocene, Miocene and younger effusions have been largely limited to the southern areas that experienced ridge collision. The Miocene and younger flood basalts (Fig. 4) can be divided into a late Miocene field that lies mainly south of $48^{\circ} \mathrm{S}$, and a northern field of Pliocene-Pleistocene age from $48^{\circ}$ to $47^{\circ} \mathrm{S}$ (Ramos and Kay, 1991). These two areas of diachronous alkali basaltic volcanism are located over projected slab windows that evolved from the middle to late Miocene subduction of the Chile Rise south of the Esmeralda Fracture Zone 


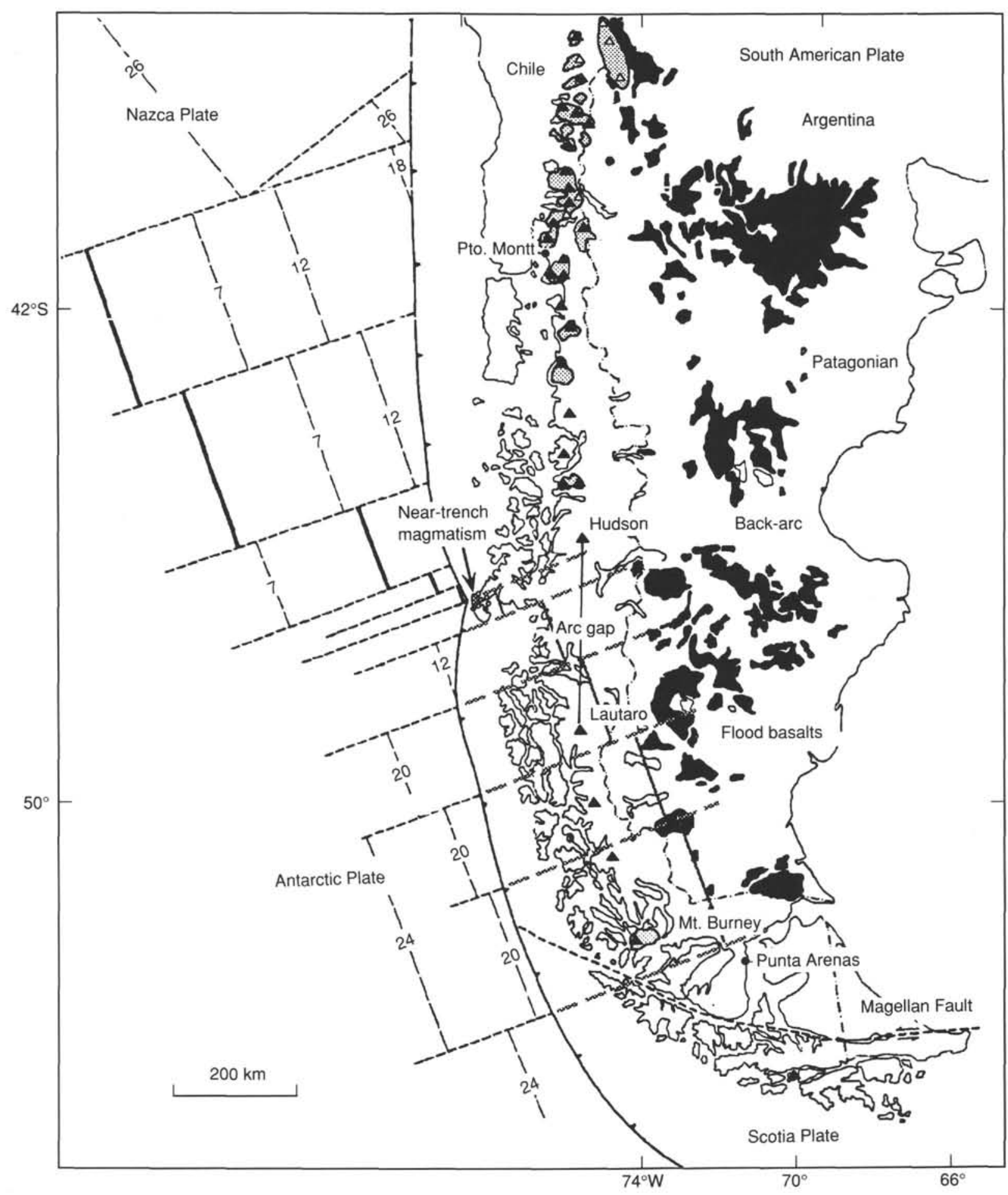

Figure 3. Late Cenozoic forearc, arc, and backarc magmatic provinces of the southern Andes. Forearc magmatism is documented only from the Taitao Peninsula. Arc magmatism is divided into a northern "Southern Volcanic Zone" and a southern "Austral Volcanic Zone" of composite stratovolcanoes. Backarc volcanism is represented by Tertiary fields of alkalic flood basalts.

and the latest Miocene to Pliocene subduction of the spreading segment located between the Esmeralda and Tres Montes fracture zones (op. cit.). In contrast to the response seen in the arc volcanism, where a hiatus can be found as the slab window passes under the arc, the backarc area over the window becomes an area of extensive basaltic volcanism.

\section{LATE TERTIARY TECTONIC EFFECTS OF TRIPLE JUNCTION MIGRATION}

Tectonic effects seen in the on-land geology that resulted from migration of the CTJ include (1) uplift, exhumation, and deformation of the Taitao Ophiolite, (2) right lateral motion along the 

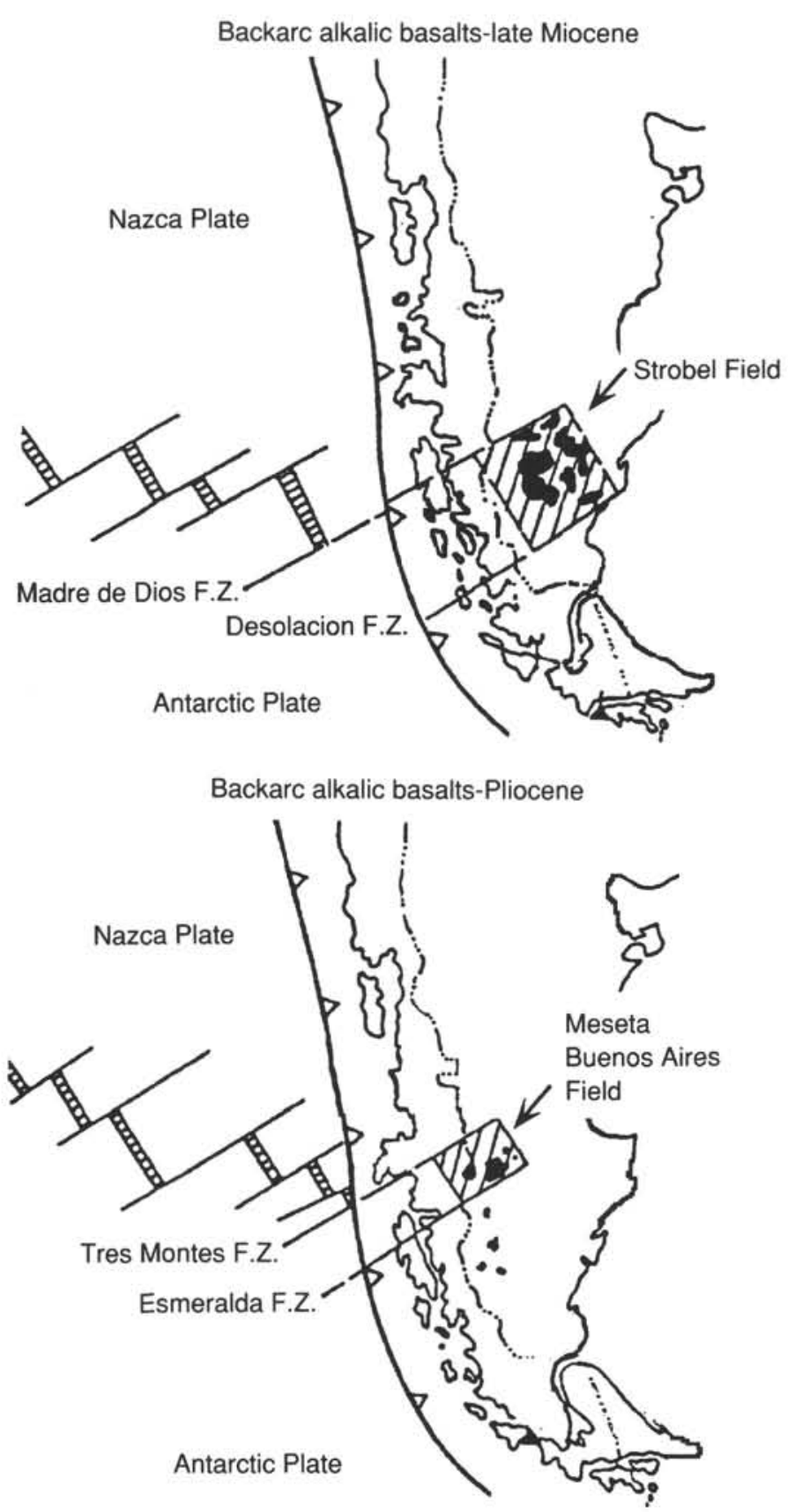

Figure 4. Migration of centers of late Tertiary backarc alkalic basalts in Patagonia and their correlation with estimates of the subducted edges of the Antarctic and Nazca plates.

LOF and fault-driven basin subsidence in the Golfo de Penas Basin, (3) differential uplift of the Andean Cordillera, (4) differential backarc deformation, and (5) continental seismicity.

\section{Tectonism in the Taitao Ophiolite}

Uplift/exhumation is likely to have occurred rapidly during the late Pliocene or Pleistocene, as the high peaks within the lower gabbros were extensively glaciated during the Holocene. The ophiolite has a lower (southern) fault contact that places serpentinized ultramafic rocks up against the Pliocene Cabo Rapier granodiorite (Fig. 2), and tectonic contacts can be seen within the ophiolite sequence.
Cande and Leslie (1986) demonstrated that the small ridge segments between the Tres Montes, Taitao, and Darwin fracture zones have small amounts of overlap along the trench in their areas of impingement. This is a result of the Nazca/South American convergence direction being slightly more easterly than the azimuth of the transforms. As a consequence, small areas along the margin see two ridge-collision events. The north end of the Taitao Ophiolite sits at the latitude of the Taitao Fracture Zone and has experienced a double collision. While the origin of the ophiolite appears to correlate in time with the arrival of the first ridge segment during the latest Miocene to Pliocene, its uplift and exhumation may represent the arrival of the next segment to the north. If so, then the uplift of the ophiolite probably began approximately 1 to $2 \mathrm{~m}$.y. ago.

\section{The Liquiñe Ofqui Fault}

The most important structure seen inland of the present triple junction is the LOF system (Moreno and Parada, 1976; Hervé et al., 1974; Hervé, 1976; Hervé, 1984; Thiele et al., 1986). In Figure 5 , the general trace of this fault system and an accompanying satellite view of its geomorphic expression are shown. The fault extends at least $1000 \mathrm{~km}$ from the small town of Liquiñe in the north, along the central axis of the SVZ, to the Isthmus of Ofqui, near the northwest corner of the Golfo de Penas. To the south, the LOF appears to curve westward into the Golfo de Penas. It has not been traced south of the Chile Triple Junction.

Thiele et al. (1986) indicated that the fault affects rocks aged from 10 to $4 \mathrm{Ma}$. Hervé (1976) mapped a 3-km-wide cataclastic and mylonitic zone in the Liquiñe area. Similar fault rocks can be found where the geomorphic trace of the fault is accessible. Minor structures indicate that the dominant movement sense is dextral. In addition, late Miocene and Pliocene magmatic rocks show clockwise-rotated populations of their characteristic remanence directions near the LOF (Garcia et al., 1988). At Laguna San Rafael $1200 \mathrm{~m}$ of relative subsidence over a maximum of $3 \mathrm{~m} . \mathrm{y}$. is documented immediately west of the LOF (Muir-Wood, 1989). Here, the fault is oriented slightly clockwise of the dominant orientation to the north and dips $60^{\circ}$ to $70^{\circ} \mathrm{W}$. The subsidence can be interpreted as the result of a dip-slip component on an oblique slip portion of the LOF. If this is the case, minimum rates of dextral motion on the LOF of $1 \mathrm{~mm} / \mathrm{yr}$ can be estimated.

Current activity of the LOF is attested to by the presence of hot springs (Hauser, 1989) and cinder cones (Hauser, pers. comm., 1992) along the fault trace. Aftershock events of the great earthquake of 1960 occurred along the LOF and dextral strike-slip fault-plane solutions have been established (Cifuentes, 1989).

The Golfo de Penas (Fig. 6) represents a major embayment along the Pacific coast of the Andes that brings the Pacific Ocean more than $100 \mathrm{~km}$ into the interior of the Andes, essentially up the line of the Quaternary volcanic arc. The southern and central portions of the Golfo de Penas saw the arrival of the Chile Rise at about 5 to $6 \mathrm{Ma}$, while the northwestern arm of the basin, which is presently uplifted within the Taitao Peninsula region, saw collision more recently at 3 to $1.5 \mathrm{Ma}$ (Cande and Leslie, 1986).

In the outer regions of the margin, both to the north and south of the entrance to the Golfo, black to gray carbonaceous clastic sequences of Eocene age lie unconformably over forearc basement or over Late Cretaceous magmatic rocks (Forsythe et al., 1985; Mpodozis et al., 1985; De Vries and Stott, 1984). The uplifted Eocene sections may be 2 to $3 \mathrm{~km}$ thick. In addition, 2 $\mathrm{km}$ of Oligocene to Miocene shallow marine/deltaic sandstones and siltstones having thin calcareous sandstones and siltstones have been reported (Forsythe et al., 1985) from the Taitao Peninsula and Tres Montes Peninsula regions.

Seismic reflection surveys (Mordojovich, 1981) document a minimum of 2 to $3 \mathrm{~s}$ two-way traveltime of sedimentary infill with 


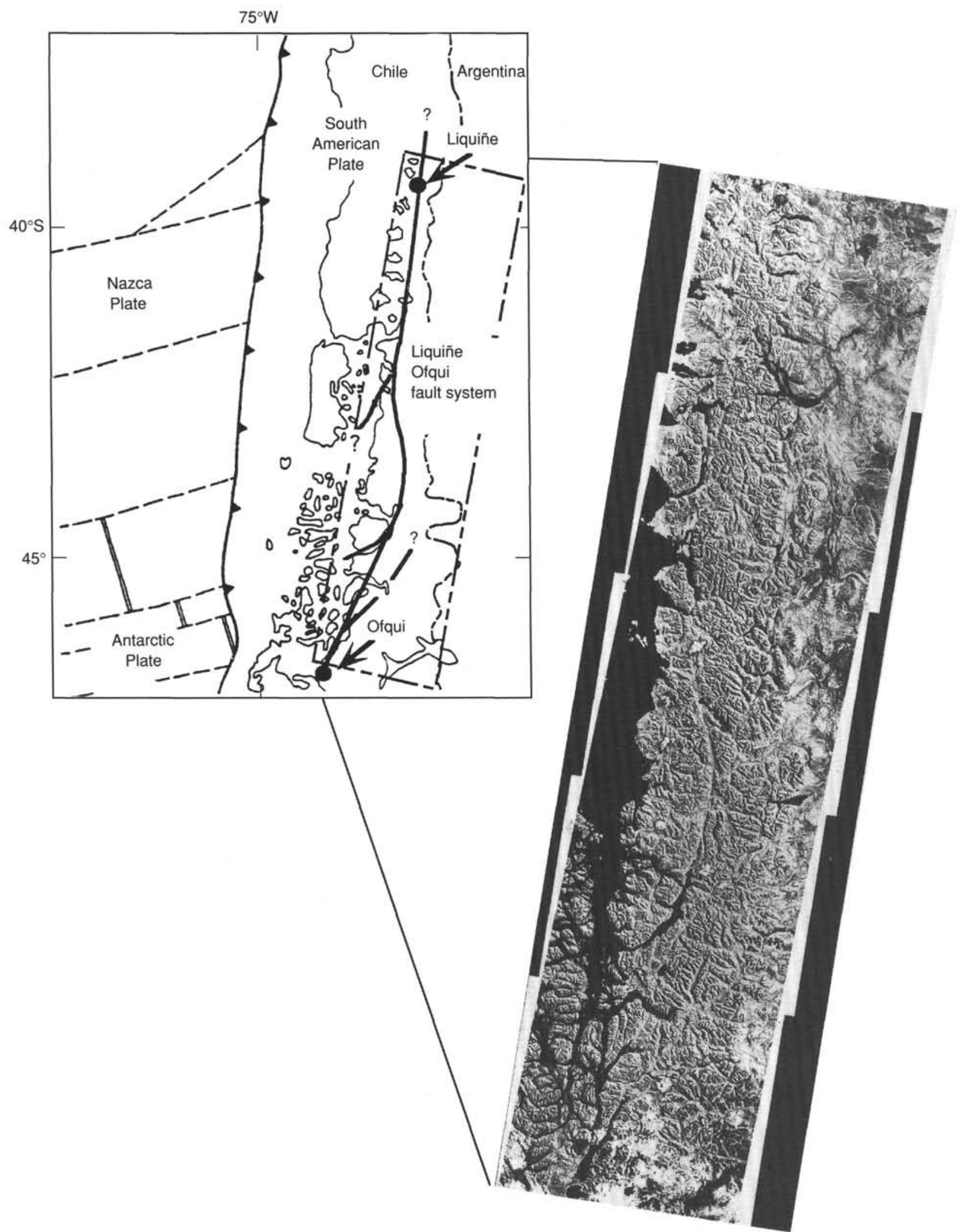

Figure 5. Landsat (MSS) montage and location map showing the LOF. Note the snow-capped Holocene volcanic centers of the SVZ located along the fault system. Landsat montage was processed using MSS Band 3, from scenes acquired in August 1985. 


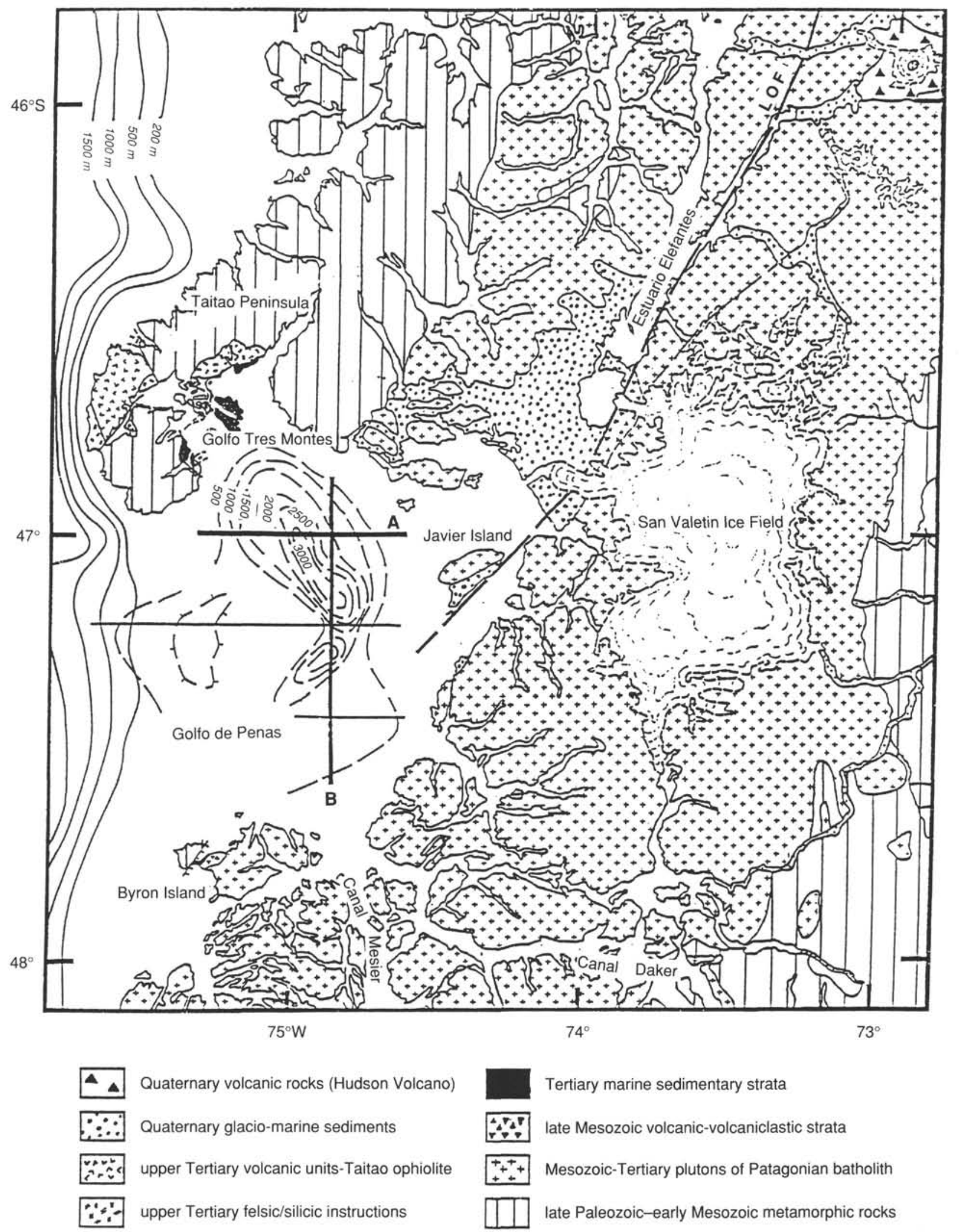

Figure 6. Map of the Golfo de Penas showing the distribution of Tertiary marine sedimentary sequences in the surrounding shores and the offshore basin within the golfo. The estimated isopach lines are based on an average velocity of $2.5 \mathrm{~km} / \mathrm{s}$ for sediments imaged in the four lines shown. 
a number of steep faults that appear to be related to basin subsidence. Tracings of significant bedding reflectors and faults within two of these lines are shown in Figure 7. The western portions of the east-west line (Line A, Fig. 6) have a tilted and eroded series of strata about 3 to $4 \mathrm{~km}$ thick dipping eastward into the main north-northwest/south-southeast axial trough of the basin. Both the east-west and north-south lines are cut by faults. The northsouth line (Line B, Fig. 6) shows that the axial portion of the basin has a graben appearance with a hanging-wall anticline imaged above one of the steep trough-bounding faults. An increase in the dip of hanging-wall strata with increasing depth documents the progressive subsidence of the basin during extensional faulting. Offsets of the seafloor across several of the faults indicate that faulting and basin subsidence still are continuing. Mesofault data collected in the uplifted rocks surrounding the Golfo indicate that Cenozoic brittle faulting has occurred in the region in both northeast- and northwest-trending sets with both normal and strike-slip components of motion consistent with north-south extension and east-west compression (Forsythe and Nelson, 1985).

A preliminary correlation between the sections exposed on land and those imaged within the Golfo on the seismic lines was made by Forsythe and Nelson (1985). The extension and subsidence in the Golfo de Penas Basin may have had an early Eocene phase of activity. However, it is also clear that substantial Miocene to Holocene fault-related subsidence $(>2 \mathrm{~km})$ occurred. This fault-controlled extension within the Golfo de Penas has been postulated to represent a pull-apart basin at the southern edge of the LOF system, essentially accommodating the northward displacement of a 1000-km-long block of the South American forearc relative to the arc or backarc provinces of the South American Plate (Forsythe and Nelson, 1985).

\section{Tertiary Andean Uplift}

During the late Cenozoic, the main Andean Cordillera north and south of the present position of the triple junction underwent significantly different uplift histories (Ramos, 1988). North of $46^{\circ} \mathrm{S}$, peaks rarely exceed $2000 \mathrm{~m}$, whereas to the south of the triple junction, the highest peaks (such as Cerro San Lorenzo) exceed 3000 to $4000 \mathrm{~m}$ (Ramos, 1989; Ramos and Kay, 1991). North of the triple junction, the continental divide comprises a semicontinuous series of Pliocene and Pleistocene volcanic centers; to the south, however, the Andes are dominated by deeper crustal complexes of magmatic and metamorphic rocks (Fig. 1). A minimum of 2 to $3 \mathrm{~km}$ difference in late Cenozoic uplift history appears south and north of the triple junction.

\section{Backarc Deformation}

The Tertiary molasse sequences thin dramatically from south to north at approximately the latitude of the triple junction (Marshall et al., 1977; Ramos and Kay, 1991) corresponding to a contrast in backarc deformation. At latitudes $46.5^{\circ}$ to $48^{\circ} \mathrm{S}$, the structure of the foreland is that of a fold-and-thrust belt. Individual thrusts die out between $46^{\circ}$ and $47^{\circ} \mathrm{S}$. To the north, it has been argued that deformation within the foreland only involves a slight reactivation on older extensional faults that were initiated during an extensional phase of deformation during the middle Mesozoic (Ramos, 1989; Ramos and Kay, 1991).
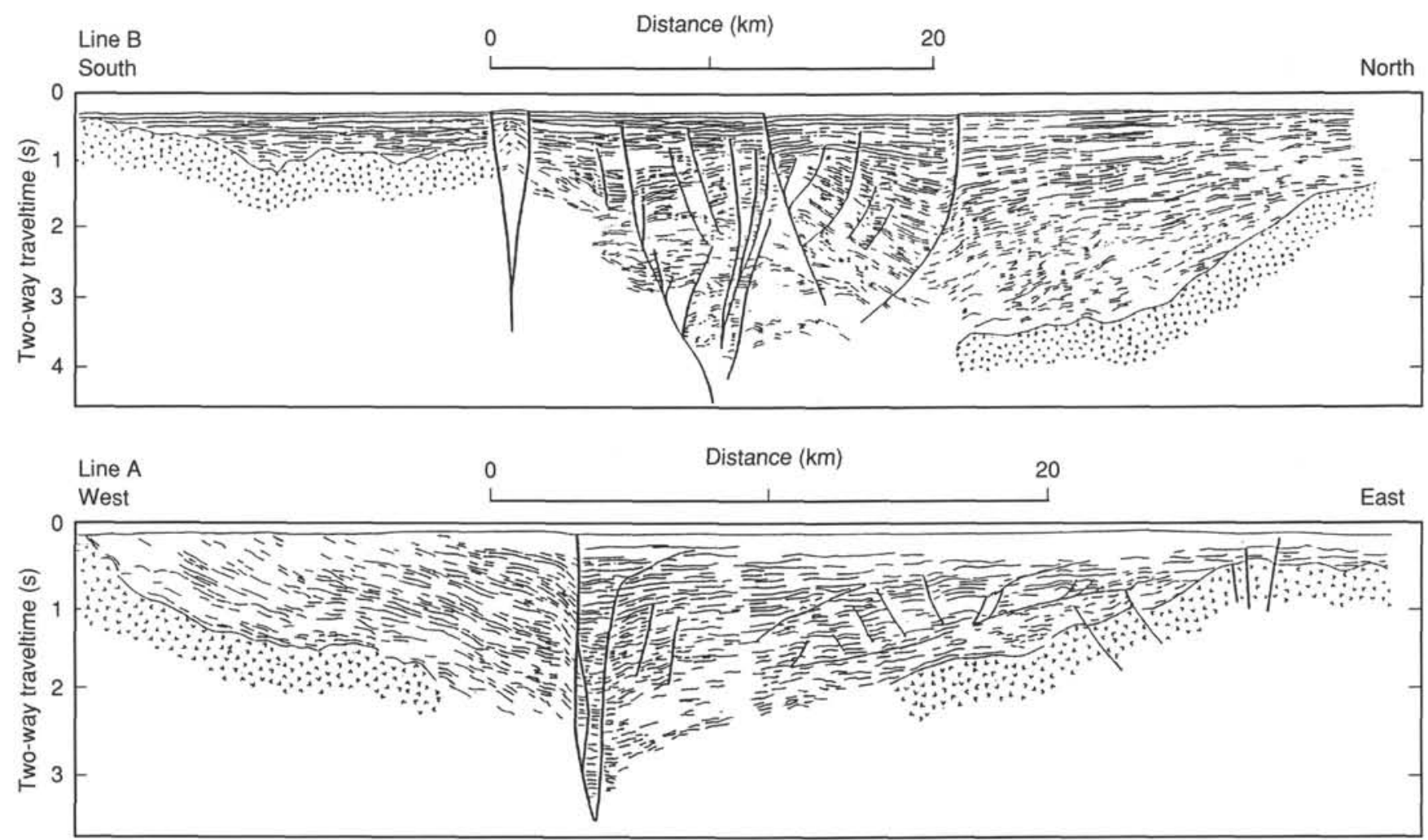

Figure 7. Line drawing of bedding and fault traces imaged in two of the four migrated seismic lines from the Golfo de Penas. The original lines were provided courtesy of ENAP, Santiago (Chile). Subsidence related to normal faults that bound the axial portion of the basin is clearly documented in the upper line. The lower line appears to cross a steeper fault that may have a strike-slip component. Active faulting in the basin is suggested by offsets of the seafloor over faults. 
The correlation between the change in thickness of the foreland molasse, the style and amount of crustal shortening within the foreland, and the level of unroofing (the high Andes lie to the west of the foreland) are all compelling observations for ridge-related processes of backarc deformation. Ramos (1989) argued that the region to the south of the triple junction saw the last phase of Miocene foreland contraction prior to the eruption of flood basalts of latest Miocene age.

\section{Seismicity}

All published data relating to seismicity in the CTJ region are teleseismically recorded with a lower threshold having a magnitude of about 4 or 5 . The downgoing ridge transform system is seismically active (Forsyth, 1975). North of the CTJ, the Benioff Zone is defined by trench seismicity, whereas to the south, no trench events have been recorded (op. cit.). North of the CTJ, seismic slip rates are comparable with plate tectonic rates (Kanmori, 1977), although Barrientos and Ward (1990) identified segments where aseismic slip has been important. Continental seismicity has been characterized by large events ( $>$ M8) having a long repeat time $(500 \mathrm{yr})$. The great earthquake of 1960 ruptured parallel to the LOF for $930 \mathrm{~km}$ (Cifuentes, 1989), giving rise to major forearc uplift over $800 \mathrm{~km}$ of the rupture length (Pflaker and Savage, 1970; Barrientos and Ward, 1990). The rupture propagated from north to south after a complex foreshock array close to the hypocenters of the second-stage main shock. Rupture arrest occurred close to the CTJ. The fault plane solutions indicate that the great earthquake kinematics closely match the subduction system north of the CTJ. The rupture and arrest pattern suggest that there is also a close association with the CTJ and the LOF and that the rupture is bound by major fractures in the oceanic lithosphere (Barrientos and Ward, 1990). Recognition of seismic events parallel and kinematically equivalent to oceanic fracture systems (Kanmori and Stewart, 1979) lends further evidence for the influence of oceanic structure on continental seismicity.

\section{REFERENCES}

Almeida, F.F., et al., 1978. Tectonic map of South America. DNPMCGMW-UNESCO, Rio de Janeiro, Brazil.

Barrientos, S.E., and Ward, S.N., 1990. The 1960 Chile earthquake: inversion for slip distribution from surface deformation. Geophys. J. Int., 103:589-598.

Bruhn, R.L., Stern, C.R., and DeWitt, M.J., 1978. Field and geochemical data bearing on the development of a Mesozoic volcanic-tectonic and back-arc basin in southernmost South America. Earth Planet. Sci. Lett., 41:32-46.

Cande, S.C., and Leslie, R.B., 1986. Late Cenozoic tectonics of the Southern Chile Trench. J. Geophys. Res., 91:471-496.

Cifuentes, L.I., 1989. The 1960 Chilean earthquakes. J. Geophys. Res., $94: 665-680$.

Cummings, D., and Shiller, G.I., 1971. Isopach map of the earth's crust. Earth Sci. Rev., 7:97-125.

De Vries, T.J., and Stott, L., 1984. Neogene fossiliferous deposits in Southern Chile. U.S. Antarct. J., 19:12-13.

Escobar, T., et al. (Eds.), Mapa Geologico de Chile, 1980. Serv. Nac. Geol. Miner., Santiago, Chile.

Forsyth, D., 1975. Fault plane solutions and tectonics of the South Atlantic and Scotia Sea.J. Geophys. Res., 80:1429-1443.

Forsythe, R.D., 1982. The late Paleozoic to early Mesozoic evolution of southern South America: a plate tectonic interpretation. J. Geol. Soc. London, 139:671-682.

Forsythe, R.D., and Nelson, E., 1985. Geologic manifestations of ridge collision; evidence from the Golfo de Penas-Taitao Basin, southern Chile. Tectonics, 4:447-495.

Forsythe, R.D., Nelson, E.P., Carr, M.J., Kaeding, M.E., Hervé, M., Mpodozis, C., Soffia, J.M., and Harambour, S., 1986. Pliocene near- trench magmatism in southern Chile: a possible manifestation of ridge collision. Geology, 14:23-27.

Forsythe, R.D., Olsson, R.K., Johnson, C., and Nelson, E.P., 1985. Stratigraphic and micropaleontologic observations from the Golfo de Penas-Taitao Basin, southern Chile. Rev. Geol. Chile, 25/26:3-12.

Garcia, A.R., Beck, M.E., Burmester, R.F., Munizaga, F., and Hervé, F., 1988. Paleomagnetic reconnaissance of the Region de Los Lagos, southern Chile, and its tectonic implications. Rev. Geol. Chile, 15:1330.

Gust, D.A., Biddle, K.T., Phelps, D.W., and Uliana, M.A., 1985. Associated Middle to Late Jurassic volcanism and extension in southern South America. Tectonophysics, 116:223-253.

Hauser, A., 1989. Fuentes termales y minerales en torno a la Carretera Austral, Regiones X, XI. Rev. Geol. Chile, 16:229-240.

Hervé, F., 1984. Rejuvenecimiento de edades radiometricas en la zona de falla Liquiñe-Ofqui, en Aisen. Comunicaciones, 34:107-115.

Hervé, F., Godoy, E., Garrido, I., Hormazabal, L., Brook, M., Pankhurst, P.J., and Vogel, S., 1988. Geochronologia y condiciones de metamorfismo del complejo de subduccion del archipielago de los Chonos. Act. Congr. Geol. Chileno, 5:E157-173.

Hervé, F., Godoy, E., Parada, M., Ramos, V., Rapela, C., Mpodozis, C., and Davidson, J., 1987. A general view of the Chilean-Argentine Andes, with emphasis on their early history. Am. Geophys. Union Geodyn. Ser., 18:97-113.

Hervé, F., Moreno, H., and Parada, M.A., 1974. Granitoids of the Andean Range of Valdivia Province, Chile. Pac. Geol., 8:39-45.

Hervé, F., Mpodozis, M., Davidson, J., and Godoy, E., 1981. Observaciones estructurales y petrograficas en el Basemento Metamorfico del Archipielago de los Chonos, entre el Canal King y el Canal Ninalac, Aysen. Rev. Geol. Chile, 13/14:3-16.

Hervé, M., 1976. Estudio geologico de la Falla Liquiñe-Reloncavi en el area de Liquifie: antecedenes de un movimiento transcurrente (Provincia de Valdivia). Act. Congr. Geol. Chileno, 1:B39-B56.

Kaeding, M.E., Forsythe, R.D., and Nelson, E.P., 1990. Geochemistry of the Taitao ophiolite and near trench intrusions from the Chile Margin Triple Junction. J. South. Am. Earth Sci., 3:161-177.

Kanmori, H., 1977. Seismic and aseismic slip along subduction zones and their tectonic implications. In Talwani, M., and Pitman, W.C., III (Eds.), Island Arcs, Deep Sea Trenches and Back Arc Basins. Am. Geophys. Union, Maurice Ewing Ser., 1:99-114.

Kanmori, H., and Stewart, G.S., 1979. A slow earthquake. Phys. Earth Planet. Int., 18:167-175.

Katsui, Y., 1972. Late Cenozoic petrographic provinces of the volcanic rocks from the Andes to Antarctica. In Adie, R.D. (Ed.), Antarctic Geology and Solid Earth Geophysics: Oslo, 181-185.

Lopez-Escobar, L., Frey, F.A., and Vergara, M., 1977. Andesites and high-alumina basalts from the central-south Chile High Andes: geochemical evidence bearing on their petrogenesis. Contrib. Mineral. Petrol., 63:199-228.

Malumian, N., and Ramos, V.A., 1984. Magmatic intervals, transgression-regression cycles and oceanic events in the Cretaceous and Tertiary of southern South America. Earth Planet. Sci. Lett., 67:228237.

Marshall, L.G., Pascual, R., Curtis, G.H., and Drake, R. E., 1977. South American geochronology: radiometric time scale for middle to late Tertiary mammal-bearing horizons in Patagonia. Science, 195:13251328.

Mordojovich, H.C., 1981. Sedimentary basins of Chilean Pacific Offshore. In Halbouty, M.C. (Ed.), Energy Resources of the Pacific Region. AAPG, 12:63-82.

Moreno, H., and Parada, M.A., 1976. Esquema geologico de la Cordillera de los Andes entre los paralelos $39^{\circ}$ y $41^{\circ} 30^{\prime}$ Lat. S., Act. Congr. Geol. Chileno, 1:A213-226.

Mpodozis, C., Hervé, M., Nasi, C., Forsythe, R.D., and Nelson, E.P., 1985. El magmatismo Plioceno de Peninsula Tres Montes, y su relacion con la evolution del Punto Triple de Chile Austral. Rev. Geol. Chile, 25/26:13-28.

Muir-Wood, R., 1989. Recent normal faulting at Laguna de San Rafael, Aisen province, Southern Chile. Comunicaciones, 40:57-68.

Munizaga, F., Hervé, F., Drake, R., Pankhurst, R.J., Brook, M., and Snelling, N., 1988. Geochronology of the Lake District of south-cen- 
tral Chile $\left(39^{\circ}-42^{\circ} \mathrm{S}\right)$ : preliminary results. J. South Am. Earth Sci., 1:309-316.

Nelson, E., Bruce, B., Elthon, D., Kammer, D., and Weaver, S., 1988. Regional lithologic variations in the Patagonian batholith. J. South Am. Earth Sci., 1:239-248.

Pankhurst, R.J., Hervé, F., Rojas, L., and Cembrano, J., 1992. Magmatism and tectonics in continental Chiloe, Chile $\left(42^{\circ}-42^{\circ} 30 \mathrm{~S}\right)$. Tectonophysics, 205:283-294.

Pflaker, G., and Savage, J.C., 1970. Mechanism of the Chilean earthquakes of May 21 and 22, 1960. Bull. Geol. Soc. Am., 81:1001-1030.

Ramos, V.A., 1988. La estructura de la Cordillera Patagonica $\left(47-49^{\circ} \mathrm{S}\right)$ de Argentina y Chile. Act. Congr. Geol. Chileno, 1:A101-A114.

, 1989. Foothills structure in the Northern Magallanes Basin, Argentina. AAPG Bull., 73:887-903.

Ramos, V.A., and Kay, S.M., 1991. Southern Patagonian plateau basalts and deformation: backarc testimony of ridge collisions. Tectonophysics, 205:261-282.
Skarmeta, J., 1978. Region continental de Aysen entre el lago General Carrere y la Cordillera Castillo. Serv. Nac. Geol. Miner., Carta Geol. Chile, 29.

Thiele, R., Hervé, F., Parada, M.A., Godoy, E., 1986. La Megafalla Liquiñe-Ofqui en el Fiordo Reloncavi $\left(41^{\circ} 30\right)$, Chile. Comunicaciones, 37:31-47.

Thorpe, R.S., and Francis, P.W., 1979. Variations in Andean andesite compositions and their petrogenetic significance. Tectonophysics, 57:53-70.

Vergara, M., and Munizaga, F., 1974. Age and evolution of the upper Cenozoic volcanism in central-south Chile. Bull. Geol. Soc. Am., 85:603-606.

\section{Ms 141IR-103}

